This item was submitted to Loughborough's Research Repository by the author.

Items in Figshare are protected by copyright, with all rights reserved, unless otherwise indicated.

\title{
Modelling the potential to achieve deep carbon emission cuts in existing UK social housing: the case of Peabody
}

PLEASE CITE THE PUBLISHED VERSION

http://dx.doi.org/10.1016/j.enpol.2010.03.054

PUBLISHER

(c) Elsevier

VERSION

AM (Accepted Manuscript)

LICENCE

CC BY-NC-ND 4.0

\section{REPOSITORY RECORD}

Reeves, Andrew, Simon Taylor, and Paul R. Fleming. 2019. "Modelling the Potential to Achieve Deep Carbon Emission Cuts in Existing UK Social Housing: The Case of Peabody". figshare.

https://hdl.handle.net/2134/13128. 
This item was submitted to Loughborough's Institutional Repository (https://dspace.lboro.ac.uk/) by the author and is made available under the following Creative Commons Licence conditions.

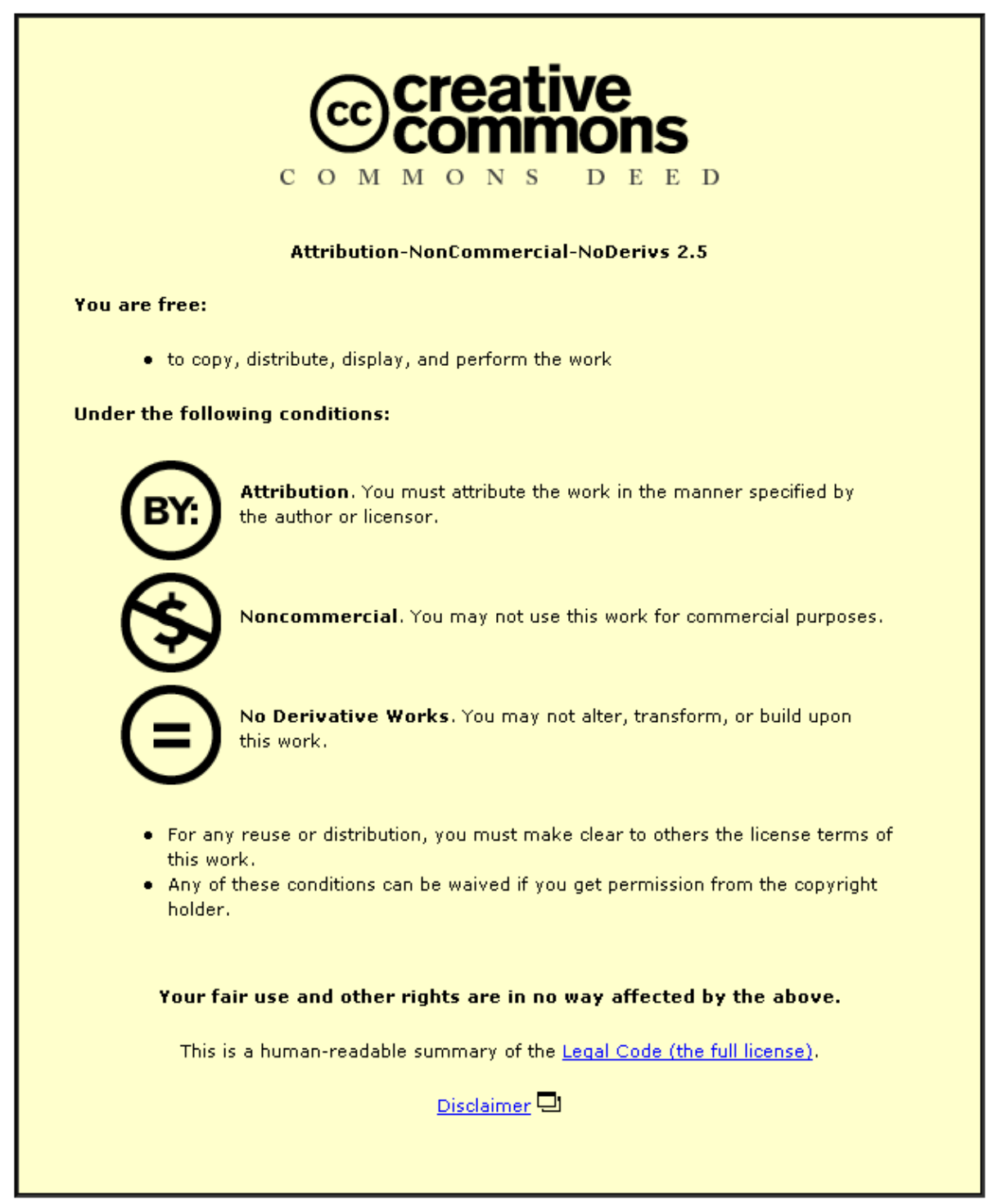

For the full text of this licence, please go to: http://creativecommons.org/licenses/by-nc-nd/2.5/ 


\title{
Modelling the potential to achieve deep carbon emission cuts in existing UK social housing: the case of Peabody
}

\author{
Andrew Reeves* \\ Simon Taylor \\ Paul Fleming
}

Institute of Energy and Sustainable Development, De Montfort University, Leicester, LE1 9BH, UK.

*Corresponding author. Tel: +44-116-2551551, extension 6848; Fax: +44-116-2577981 E-mail address: areeves@dmu.ac.uk (A. Reeves).

\section{Abstract}

As part of the UK's effort to combat climate change, deep cuts in carbon emissions will be required from existing housing over the coming decades. The viability of achieving such emission cuts for the UK social housing sector has been explored through a case study of Peabody, a housing association operating in London. Various approaches to stock refurbishment were modelled for Peabody's existing stock up to the year 2030, incorporating insulation, communal heating and micro-generation technologies. Outputs were evaluated under four future socio-economic scenarios. The results indicate that the Greater London Authority's target of a 60\% carbon emission cut by 2025 can be achieved if extensive stock refurbishment is coupled with a background of wider societal efforts to reduce carbon emissions. The two key external requirements identified are a significant reduction in the carbon intensity of grid electricity and a 
stabilisation or reduction in householder demand for energy. A target of achieving zero net carbon emissions across Peabody stock by 2030 can only be achieved if grid electricity becomes available from entirely zero-carbon sources. These results imply that stronger action is needed from both social landlords and Government to enable deep emission cuts to be achieved in UK social housing.

\section{Keywords}

domestic carbon emissions; existing social housing; zero carbon

\section{Introduction}

Over the coming decades, the UK faces the considerable challenge of achieving deep cuts in carbon emissions from its existing housing stock, as part of the global effort to combat climate change. Social housing makes up around a fifth of UK homes, and social housing providers are likely to be at the forefront of efforts to comprehensively refurbish existing UK housing to achieve substantial emission cuts. This research has explored the viability of achieving deep carbon emission cuts (defined here as reductions of the order of $60 \%$ or beyond) within existing social housing. This was carried out through a case study focusing on one UK housing association, Peabody (formerly the Peabody Trust), that manages 18,000 homes in London. The stock refurbishment measures required to achieve deep emission cuts for Peabody's existing stock have been assessed, alongside the impact of a number of contextual factors (such as resident demand for energy) that influence the measures that Peabody are able to carry out and the emission cuts achieved. The research reported here is part of a more extensive study incorporating analysis of the affordability, viability and acceptability of the measures considered in this paper, reported in full in Reeves (2009). 
Progress on carbon emission reduction was assessed against the GLA's target of a $60 \%$ reduction in London emissions by 2025 relative to a 1990 baseline (GLA, 2007) and the aspiration of achieving zero net carbon emissions for Peabody stock by 2030 . The former is the key political target applying to Peabody for the period considered in this study (up to 2030), and is based upon the same aspiration for stabilisation of atmospheric carbon dioxide levels as the UK Government's longer term target of achieving $80 \%$ emission cuts by 2050 (DECC 2009). Based upon the carbon budget given in GLA (2007) for existing housing emissions in 2025, and assuming further emissions arising out of the construction of planned new housing up to that date, the GLA target translates into an average reduction of emissions from existing housing in London of $57.4 \%$ by 2025 (Reeves, 2009). This was used to assess progress by Peabody in meeting the GLA target. The zero carbon target is put forward as an upper level aspiration to explore the viability of the calls from some studies (such as CAT, 2007; PIRC, 2008) for much more rapid decarbonisation of the UK economy.

\section{Background}

\subsection{The context of low-carbon refurbishment in the UK}

The need for a substantial programme of refurbishment of the UK's existing housing stock to both mitigate climate change and reduce levels of fuel poverty is well established amongst practitioners and researchers in the fields of housing and energy efficiency (Boardman et al., 2005; EST, 2008; UKGBC, 2008).

Despite this identified need, progress to date in carrying out this work has been slow. Government policy and grant funding is still largely focused on carbon reduction measures with low upfront costs and short payback periods such as cavity wall insulation and loft insulation. Installation rates for more costly measures, such as solidwall insulation and micro-generation technologies, are some way below those required 
for a pathway towards meeting the government's long term carbon reduction targets (WWF, 2008; CCC, 2009). Comprehensive whole-house refurbishments, incorporating measures to reduce the rate of heat loss, control ventilation and generate heat and power, are likely to be required to achieve deep emission cuts in the housing sector, but to date very few homes in the UK are being refurbished to such a standard (Killip, 2008).

Government policy is beginning to focus on mechanisms for delivering these measures on a large scale and for removing financial barriers to undertaking this work (DECC, 2009). Two new mechanisms which will be trialled in the near future include the Community Energy Saving Programme (CESP), which will trial area-based wholehouse refurbishments (ibid) and Pay As You Save (PAYS) funding approaches, which remove the upfront costs of installing more capital-intensive measures (UKGBC, 2009). The potential effectiveness of the PAYS approach may be limited, due to the intention that it will only fund measures which achieve a financial payback within their lifetime (ibid). Evidence from prior research indicates that many of the technical measures required to achieve deep emission cuts may not achieve such a payback, even if fuel prices significantly increase over future years (Reeves et al. 2009).

\subsection{Research on achieving deep emission cuts}

A number of studies have explored the technical feasibility of reducing carbon emissions from the UK housing stock over the long term (Boardman et al., 2005; BRE, 2005; Boardman, 2007; Natarajan and Levermore, 2007; EST, 2008; WWF, 2008). Carbon emission reduction targets for 2050 of either $60 \%$ or $80 \%$ were explored, and each study concluded that the target considered could be achieved. In each case the most extensive deployment of technical measures considered, coupled with an assumed supportive context, was found to be necessary to meet carbon dioxide $\left(\mathrm{CO}_{2}\right)$ reduction 
targets (ibid). In the study conducted by the Energy Saving Trust this was characterised as "throwing everything at the housing stock" (EST, 2008).

Although the findings of these studies differ according to the type and extent of technologies installed, in each case a widespread uptake of micro-generation technologies alongside measures to reduce the rate of heat loss of dwellings was advocated. For example, Boardman et al. (2005) called for the use of an average of two "low or zero carbon technologies" per home, so that in a 2050 scenario that achieved $60 \%$ emission reductions, $60 \%$ of dwellings had solar thermal water heating installed, $30 \%$ had solar photovoltaics (PV), nearly $40 \%$ were heated by small scale combined heat and power (microCHP), and $20 \%$ were heated by district heating.

In addition, a number of contextual factors that play an important role in achieving deep emission cuts were identified, including decarbonisation of grid electricity, reduced demand for energy and a rapid take-up of carbon reduction technologies (Boardman, 2007; EST, 2008).

Whilst these studies each addressed the UK stock as a whole, there has been little research to date addressing the viability of achieving deep carbon reductions in particular housing sectors (e.g. owner-occupied homes, or the private rental sector). The present research addresses this gap in knowledge for the social housing sector.

\subsection{The case of UK social housing stock}

The UK social housing sector exists to provide affordable housing, with provision being approximately equally split between local authorities and housing associations. It differs markedly from other housing sectors in that it is regulated and heavily influenced by Government policy. This is exemplified by the works currently ongoing to meet the Decent Homes standard in social housing stock, which is triggering the installations of gas central heating systems and cavity wall and loft insulation. 
Government policies to drive stronger action to reduce emissions in social housing, for example, by mandating interventions to insulate solid-walled homes or to achieve minimum energy efficiency standards, have to date not been forthcoming. As a result, the extent of carbon reduction refurbishments carried out in the sector is similar to the UK housing sector as a whole, with refurbishment being largely restricted to low to medium cost measures (loft insulation, central heating installations, improved heating controls, etc) and a small number of grant-funded demonstration projects, such as European Union-funded photovoltaic installations at Peabody.

A lack of funding has been identified as a key barrier to action to retrofit existing social housing stock (Cooper and Jones, 2008). This issue is not addressed in the present paper, but was explored as part of the wider research project (Reeves, forthcoming; Reeves et al., 2009).

\section{Methods}

\subsection{Overview}

A case study method has been used for this study, enabling a detailed understanding of the technical and regulatory issues to be developed for one housing association, Peabody. The research focuses only on carbon emissions that result from direct and indirect energy use in the home, so issues such as transport and waste are excluded from the analysis. Only physical improvements to homes and changes to energy supply systems have been considered, as these are the primary responsibility of a social landlord. Measures to encourage behaviour change are therefore outside the scope of this paper, although their use by Peabody was explored in Reeves (forthcoming). The effects of distinct approaches to stock refurbishment for Peabody's existing homes were modelled up to the year 2030. The Peabody Energy Model (PEM) was developed for this research to meet this aim, using spreadsheet software to quantify energy use in 
the Peabody stock on an estate by estate basis for 189 existing estates, from the base year 2006 (the base year for the London Climate Change Action Plan) to 2030. It is assumed that Peabody's current planned work to meet the Decent Homes standard, which incorporates low-cost insulation measures, continues as planned to 2010. From 2011, the impacts on carbon emissions of various approaches to refurbishment were modelled. Four scenarios were used to specify the broader external context under which refurbishment takes place, affecting model variables such as demand for energy and the availability of district heating network connections.

Average annual carbon dioxide emissions per dwelling were calculated for each estate from 2006 to 2030 . These figures were used to assess progress for the whole stock against the GLA target and the zero emissions target. The emission reductions achieved for distinct types of Peabody stock were also assessed, so as to identify implications for the broader social housing sector.

Due to space constraints, it is not possible to report each of the many assumptions made for the PEM in this paper. The key points and a number of novel aspects of the methods used are described below. (For a full description of the PEM methodology, see Reeves, 2009.)

\subsection{Refurbishment approaches}

Four approaches to refurbishment up to 2030 were initially considered (shown in Table 1), based upon recommendations made for Peabody by prior consultancy research on their existing stock. The Base approach represents a continuation of current servicing regimes and represents Peabody's current strategy. Other approaches represent extra measures being carried out to improve the stock, with all one-off improvements being done by 2025 , so that their impact on meeting the GLA target can be identified. 
Table 1. Refurbishment approaches

\begin{tabular}{ll}
\hline Approach & Description \\
\hline Base & $\begin{array}{l}\text { After Decent Homes improvements are complete in 2010, the only } \\
\text { improvements to the fabric of Peabody Homes that are relevant for this research } \\
\text { are double-glazing installations, carried out when windows need to be replaced } \\
\text { (so that an estimated } 50 \% \text { of homes needing replacement windows are treated } \\
\text { by 2030). No changes are made to building services, except for existing boilers } \\
\text { being replaced by new efficient models at the end of their life. }\end{array}$ \\
& $\begin{array}{l}\text { From 2011, measures are applied in a single visit to each estate as required } \\
\text { from a package consisting of: solid wall insulation; double-glazing; extractor } \\
\text { fans; thermostatic radiator valves; heat meters and improved controls (for }\end{array}$ \\
& $\begin{array}{l}\text { communally heated homes); replacement of electric storage heaters with gas } \\
\text { boilers. Homes that cannot be externally insulated are insulated internally as } \\
\text { they are vacated by residents from } 2011 \text { to } 2030 .\end{array}$ \\
& $\begin{array}{l}\text { As for the Fabric approach, but estates are connected to district heating } \\
\text { networks where a connection is available, and communal heating fed by gas- } \\
\text { fired combined heat and power (CHP) is installed on other estates where } \\
\text { feasible. }\end{array}$ \\
Remmunal & $\begin{array}{l}\text { As for the Communal approach, but solar thermal panels (4m }{ }^{2} \text { ) are installed on } \\
\text { suitable top floor flats and houses, and photovoltaic (PV) panels are installed on } \\
\text { all remaining suitable roof space. }\end{array}$
\end{tabular}

These approaches have been designed specifically to be appropriate for Peabody stock, the majority of which is solid-walled, and much of which is in blocks in central London, making communal heating potentially economically viable. Many Peabody estates are in conservation areas, so a conservative assumption was made for these estates that due to concerns about maintaining their external appearance, external insulation and solar technologies could not be applied.

The impact of modifying these approaches so that the considered carbon reduction targets could be met was also explored. This included the option of temporarily rehousing (“decanting") residents so that internal insulation could be installed, and of installing a different mix of technologies, including the potential use of ground source heat pumps (GSHPs), air source heat pumps (ASHPs) and communal biomass boilers. The full list of additional approaches is listed in Table 9. 


\subsection{Modelling energy use and carbon dioxide emissions}

Carbon dioxide equivalent emissions (Defra 2007) are calculated for Peabody stock based upon assumed demand for energy, the assumed efficiencies of systems installed to provide energy services (such as heating or hot water), and assumptions on the carbon intensity of supplied energy. Energy demand assumptions were based upon equations from BREDEM (BRE 2001), a widely used model in UK research on domestic energy use, which estimates energy demand as a function of floor area and number of residents. The BREDEM equations were modified where necessary to take into account the available data for Peabody stock, the demographics of Peabody residents and assumptions relating to future scenarios. The assumed efficiencies of installed technologies were taken from the Government's SAP 2005 methodology for providing energy ratings for dwellings (BRE 2006) where possible, and from other technical literature where not.

\subsubsection{Conversion factors}

Modelled energy use was converted into carbon dioxide emissions through conversion factors for each fuel. Conversion factors for the base year 2006 are given in Table 2. The figure used for electricity exports is greater than the grid intensity assumed for electricity use, as it is based upon the principle that the use of the more carbon-intensive marginal plant used to provide for extra demand (coal and gas fired power stations) is being reduced by exports to the grid. The conversion factor for district heating is based upon data provided by Peabody on an existing district heating scheme in London that uses gas-fired CHP boilers. Biomass was assumed to be carbon neutral, as although there are clearly emissions associated with the transportation and processing of the fuel, these supply chain emissions are not considered for other conversion factors, and so for consistency, have not been considered for biomass. Beyond 2006, changes in emission factor were specified according to the four scenarios defined later in this paper. 
Table 2. Conversion factors in 2006

\begin{tabular}{lll}
\hline Category & $\begin{array}{l}\text { Conversion Factor } \\
\left(\mathbf{k g C O}_{2} \mathbf{e} / \mathbf{k W h}\right)\end{array}$ & Source \\
\hline Electricity & 0.527 & Defra (2007) \\
Gas & $0.185^{\mathrm{a}}$ & Defra (2007) \\
District Heating & 0.13 & Peabody \\
Electricity exports & 0.568 & BRE (2006) \\
Biomass & 0 & Assumed \\
${ }^{\mathrm{a}}$ A conversion factor of $0.206 \mathrm{kgCO} e / \mathrm{kWh}$ was used in error in Reeves (2009), leading to results that \\
differ slightly from those presented here.
\end{tabular}

\subsubsection{Electricity exports to the grid}

The method used for modelling exports to the grid as the carbon intensity of the grid declines requires particular attention due to the significant impact it can have on the modelled impact of low carbon technologies. It is of particular importance for the present study, as the potential for the carbon intensity of grid electricity to approach zero is considered. If the grid produces zero-carbon electricity, a reduction in net emissions for any electricity generated would no longer be appropriate, as any displaced grid electricity would be from a zero-carbon source.

Where a pathway from the original grid carbon intensity of $0.527 \mathrm{~kg} \mathrm{CO}_{2}$ per $\mathrm{kWh}$ towards zero is assumed, there is therefore a need to put forward a pathway for the carbon intensity of displaced grid electricity that arrives at the same end point (zero) at the same time. This consideration gives rise to a number of possible methods for accounting for the carbon intensity of grid electricity, described in Table 3 and illustrated in Figure 1. 
Table 3. Methods of modelling electricity exports

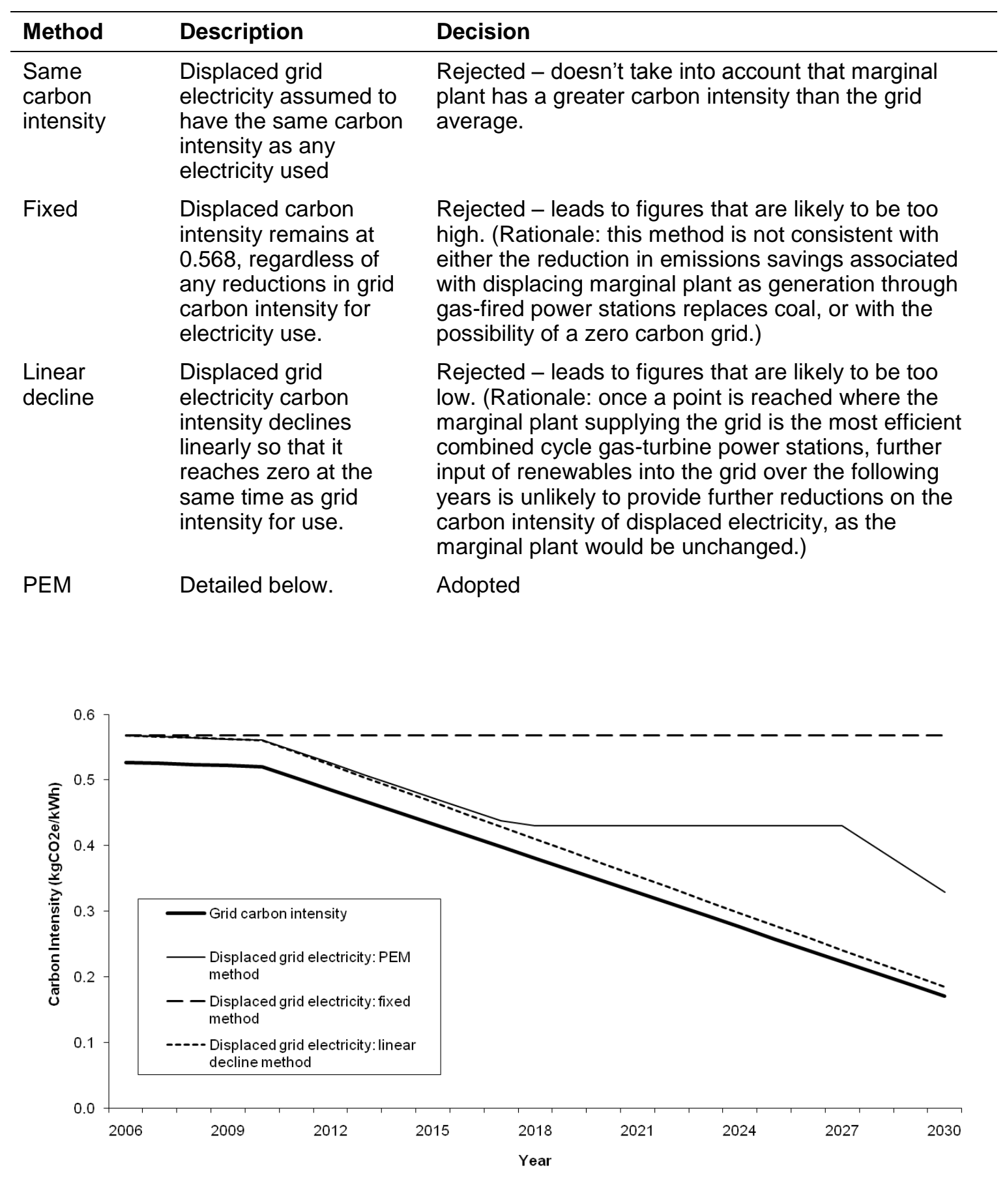

Fig. 1. Approaches to displaced grid electricity

The technique adopted represents a compromise between the limitations of the "Fixed" and "Linear Decline" methods detailed in Table 3. It describes a carbon intensity of displaced electricity that initially declines at the same rate as for grid electricity, until it 
reaches the value of $0.43 \mathrm{~kg} \mathrm{CO}_{2}$ per $\mathrm{kWh}$, the figure assumed for efficient gas-fired power stations (Defra 2007). It then plateaus as these power stations remain the source of marginal supply, despite further renewables being used to supply the grid. Assuming a pathway to a zero-carbon grid, at some point the displaced electricity carbon intensity must start declining again, as a qualitative change in the nature of electricity supply begins to take place. This research assumes that this change commences when the grid has a carbon intensity of 0.225 (notionally $50 \%$ from combined cycle gas-fired power stations, and 50\% from zero-carbon sources), starting a linear decline towards zerocarbon electricity.

\subsection{Scenarios}

Scenarios were used to specify the broad external context in the period up to 2030. Assumptions for each scenario were made to quantify the impact on model results. Four scenarios were defined by identifying key factors that are highly significant for model results, relatively independent, and which have significant uncertainty about their outcome (Schwartz, 1991).

Existing research that addresses factors affecting future domestic carbon emissions has identified a number of significant issues. These include: levels of domestic energy demand; availability of heat and electricity from renewable sources; take-up of energy saving technologies; technological innovation; economic growth; fuel costs (Boardman et al., 2005; BRE, 2005; Johnston et al., 2005; Tyndall Centre, 2005).

Bringing together the issues identified above, the two key issues used to define scenarios were the extent of action to mitigate climate change in the UK and the cost of fuel. Four scenarios were then specified (in Table 4) which take into account the interrelationships between the defining issues and other relevant issues, including those 
listed above. The key implications of these scenarios for model assumptions affecting carbon emissions are given in Table 5.

Table 4. Scenario descriptions

\begin{tabular}{ll}
\hline Scenario & Description \\
\hline $\begin{array}{l}\text { Keeping the Lights On } \\
\text { (KLO) }\end{array}$ & $\begin{array}{l}\text { Concerns about energy security over-ride action on climate change. } \\
\text { Assumed: continued economic growth, a continuation of present-day } \\
\text { Low fuel prices, weak } \\
\text { action on climate } \\
\text { change. }\end{array}$ \\
$\begin{array}{l}\text { Sustainable } \\
\text { grid electricity provided by renewables. }\end{array}$ \\
$\begin{array}{l}\text { Development (SD) } \\
\begin{array}{l}\text { Low fuel prices, strong } \\
\text { action on climate } \\
\text { change. }\end{array}\end{array}$ & $\begin{array}{l}\text { Strong measures to mitigate climate change in the context of a } \\
\text { growing economy. Assumed: substantial grant funding for } \\
\text { refurbishment, significant increases in renewables supplying the grid } \\
\text { and reduced domestic energy demand. }\end{array}$ \\
$\begin{array}{l}\text { Breaking Down (BD) } \\
\text { High fuel prices, weak } \\
\text { action on climate } \\
\text { change. }\end{array}$ & $\begin{array}{l}\text { Strong focus on energy security but with very high fuel prices } \\
\text { leading to a series of deep recessions. Assumed: marginal reduction } \\
\text { in domestic energy demand due to high prices, low use of grid } \\
\text { renewables and low Government support for domestic energy } \\
\text { saving measures. }\end{array}$ \\
$\begin{array}{l}\text { Power Down (PD) } \\
\text { High fuel prices, strong } \\
\text { action on climate } \\
\text { change. }\end{array}$ & $\begin{array}{l}\text { Strong efforts to reduce carbon emissions with a focus on reducing } \\
\text { energy demand, which partially mitigates the impact of high fuel } \\
\text { prices on fuel bills and the economy. Assumed: strong financial } \\
\text { support for refurbishment and increases in renewables supplying the } \\
\text { grid. }\end{array}$
\end{tabular}

Table 5. Relevant scenario assumptions

\begin{tabular}{|c|c|}
\hline Issue & Scenario Assumptions \\
\hline $\begin{array}{l}\text { Carbon intensity } \\
\text { of grid electricity }\end{array}$ & $\begin{array}{l}\text { Declines more rapidly in PD and SD scenarios than KLO and BD. By } 2025 \text {, } \\
\text { falls by } 29 \% \text { relative to } 2006 \text { levels for KLO/BD, and by } 51 \% \text { for SD/PD. By } \\
2030 \text {, reductions are } 39 \% \text { and } 68 \% \text { respectively. }\end{array}$ \\
\hline $\begin{array}{l}\text { Demand for } \\
\text { energy services }\end{array}$ & $\begin{array}{l}\text { KLO continues current trends, with electricity demand increasing and other } \\
\text { uses stabilising. Environmental concerns lead to reductions for SD and PD. } \\
\text { High fuel prices lead to reductions for PD and BD. Changes to } 2030 \text { for } \\
\text { electricity: }+48 \% \text { (KLO); -7\% (SD); - } 20 \% \text { (PD); +2\% (BD). Changes to } 2030 \\
\text { for other energy use: +0\% (KLO); -11\% (SD);-23\% (PD); -13\% (BD). }\end{array}$ \\
\hline $\begin{array}{l}\text { District heating } \\
\text { availability and } \\
\text { carbon intensity }\end{array}$ & $\begin{array}{l}\text { A district heating connections is available for } 10 \% \text { of estates for } \mathrm{KLO} \text { and } \mathrm{BD} \\
\text { scenarios and } 25 \% \text { for SD and PD. Carbon intensity of input fuels (originally } \\
\text { natural gas) declines by } 0.0046 \mathrm{kgCO}_{2} \mathrm{e} / \mathrm{kWh} \text { per annum for PD and SD. No } \\
\text { change for } \mathrm{KLO} \text { and BD. }\end{array}$ \\
\hline
\end{tabular}




\section{Results}

\subsection{Carbon emissions}

The emission reductions achieved by 2025 for each refurbishment approach under the four considered scenarios are shown in Figure 2. The key result is that the GLA's 2025 target can be achieved, but only in the two scenarios defined by strong action on climate change, namely SD and PD. For the KLO and BD scenarios, the most extensive approach to refurbishment considered therefore does not enable the GLA's carbon reduction target to be met. For the SD scenario, the target can be achieved through the Renewables approach. The PD scenario, which has greater assumed reductions in energy demand, can achieve the target through the Communal or Renewables approaches, and is close to doing so through fabric improvements alone. In both scenarios where the target is achieved, Peabody's current planned approach to refurbishment (the Base approach) does not achieve the required emission cuts.

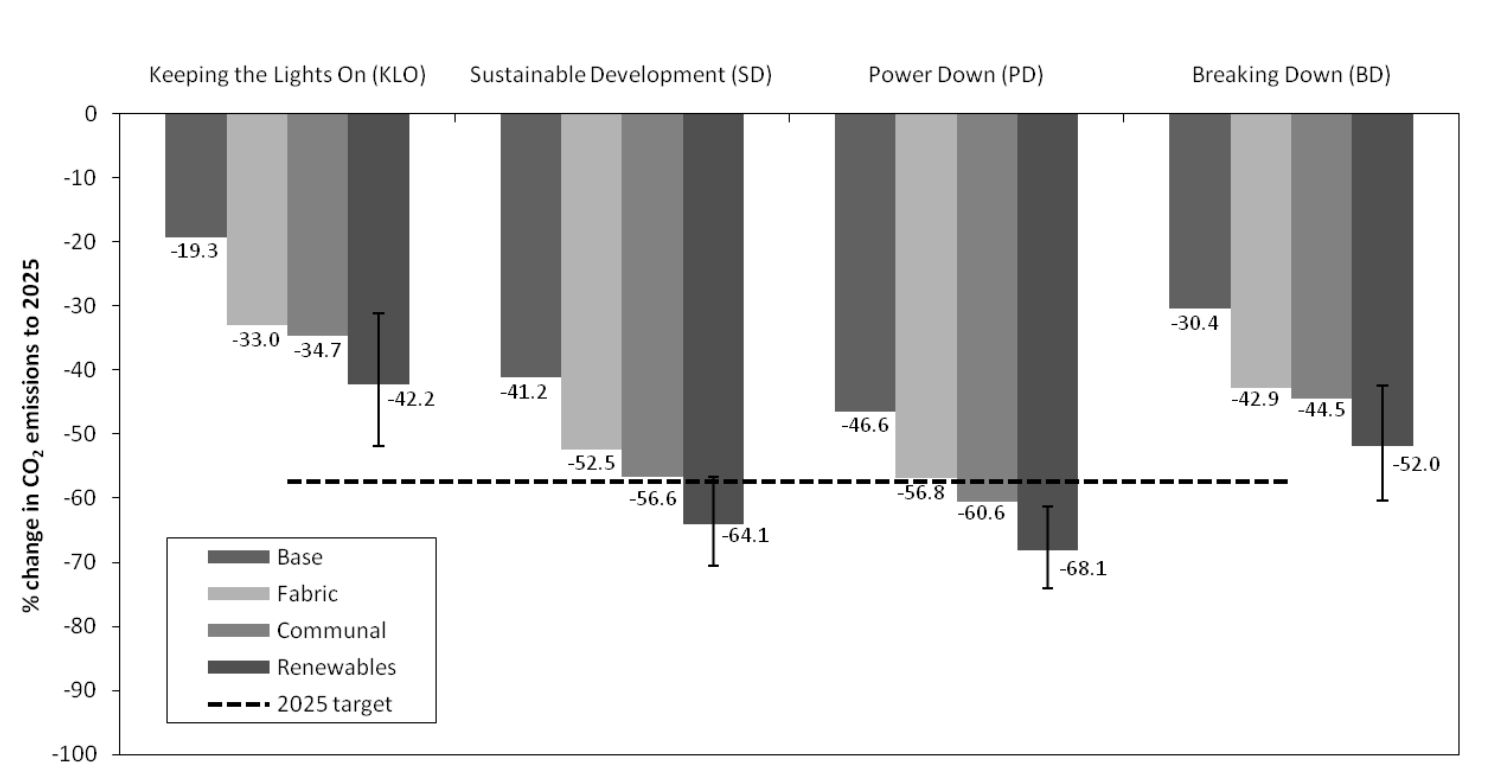

Fig. 2. Carbon emission reductions by 2025 by refurbishment approach 
The error bars in Figure 2 indicate the results of sensitivity analysis on the model outputs for the Renewables approach, illustrating the maximum and minimum reductions achieved where model variables are changed to reflect uncertainty in their values. The full results of this analysis (see Reeves 2009) indicate that the carbon intensity of grid electricity and resident demand for energy are the two contextual variables having the greatest impact on results.

To take into account the impact of this uncertainty, it is suggested that the target can be met with a good degree of confidence for a particular scenario if it is met even for the lowest possible result identified by changing model variables through sensitivity analysis. By this definition, only the Renewables approach in the PD scenario can be said to allow the 2025 target to be met with a good degree of confidence. The Renewables approach in the SD scenario is close to meeting this goal, with the lowest levels of emission reductions identified through sensitivity analysis being $56.6 \%$ (which occurs where a maximum level of energy demand for this scenario is assumed).

\subsection{Contextual factors}

The impacts of two types of contextual factor on the model results were explored: factors external to Peabody which affect the emission cuts achieved (resident demand for energy and carbon intensity of the grid) and factors which place limitations on the measures Peabody can carry out (planning constraints, and a desire to avoid disruption to residents). The latter factors were explored through their impact on the two key measures affected: solid wall insulation and solar technologies (solar thermal and solar PV).

\subsubsection{Energy demand and the carbon intensity of grid electricity}

The two external contextual factors identified as having the greatest impact on the achieved emission cuts were changes in energy demand from residents and the carbon 
intensity of grid electricity. For each factor, the values required to allow the 2025 carbon reduction target to just be achieved were calculated for each scenario. Changes in energy demand were considered by changing demand levels for heating, electricity, etc to an equal extent relative to the base year. The results (shown in Table 6) indicate a range of $+2 \%$ to $-40 \%$, with the greatest demand reductions required where there is a less extensive refurbishment approach. For the SD and PD scenarios, this result indicates that the target can be met with no reduction in energy demand.

Table 6. Resident energy demand changes to meet the GLA target

\begin{tabular}{lllll}
\hline Approach & $\begin{array}{l}\text { Keeping the } \\
\text { Lights On }\end{array}$ & $\begin{array}{l}\text { Sustainable } \\
\text { Development }\end{array}$ & Power Down & Breaking Down \\
\hline Base & $-40 \%$ & $-34 \%$ & $-34 \%$ & $-40 \%$ \\
Fabric & $-28 \%$ & $-19 \%$ & $-19 \%$ & $-28 \%$ \\
Communal & $-26 \%$ & $-12 \%$ & $-12 \%$ & $-26 \%$ \\
Renewables & $-14 \%$ & $+2 \%$ & $+2 \%$ & $-14 \%$
\end{tabular}

The results for carbon intensity of grid electricity (Table 7) demonstrate a significant difference between scenarios and approaches. The Base approach is insufficient in each scenario except PD, for which grid electricity needs to be almost entirely zero-carbon. The combination of the Fabric approach and a near to zero-carbon grid is the only way for the target to be met in the KLO scenario. The results demonstrate potential for the GLA target to be met through less extensive refurbishment if substantial reductions in the carbon intensity of the grid are achieved. For example, a 54\% reduction (giving a grid intensity of 0.24 ) would make both the Communal approach in SD and the Fabric approach in PD successful. 
Table 7. Carbon intensity of grid electricity in 2025 to meet the GLA target

\begin{tabular}{|c|c|c|c|c|}
\hline Approach & $\begin{array}{l}\text { Keeping the } \\
\text { Lights On } \\
\left(\mathrm{kgCO}_{2} \mathrm{e} / \mathrm{kWh}\right)\end{array}$ & $\begin{array}{l}\text { Sustainable } \\
\text { Development } \\
\left(\mathrm{kgCO}_{2} \mathrm{e} / \mathrm{kWh}\right)\end{array}$ & $\begin{array}{l}\text { Power Down } \\
\left(\mathrm{kgCO}_{2} \mathrm{e} / \mathrm{kWh}\right)\end{array}$ & $\begin{array}{l}\text { Breaking Down } \\
\left(\mathrm{kgCO}_{2} \mathrm{e} / \mathrm{kWh}\right)\end{array}$ \\
\hline Base & $\mathrm{N} / \mathrm{A}$ & $\mathrm{N} / \mathrm{A}$ & 0.046 & $\mathrm{~N} / \mathrm{A}$ \\
\hline Fabric & 0.046 & 0.159 & 0.246 & 0.119 \\
\hline Communal & $\mathrm{N} / \mathrm{A}$ & 0.242 & 0.329 & 0.045 \\
\hline Renewables & $\mathrm{N} / \mathrm{A}$ & 0.394 & 0.779 & 0.278 \\
\hline
\end{tabular}

\subsubsection{Use of solid wall insulation}

The scenarios modelled make the conservative assumption that solid walls are not insulated externally on listed estates or estates in conservation areas, due to concerns about maintaining the appearance of architecturally-significant buildings. Furthermore, internal insulation (for solid walls and floors) is only installed in empty properties (as they become available between tenancies) so as to avoid the extra costs and disruption involved with decanting residents from their homes.

The impact of three possible changes of these assumptions were explored by modifying the Fabric approach to refurbishment: assuming that internal insulation is not installed in empty dwellings at all; assuming that decanting is possible (so that whole estates can be decanted and then refurbished using internal wall insulation); assuming that there are no conservation area (CA) constraints, so estates in conservation areas (but not listed estates) can be externally insulated.

The impact of the considered changes is very similar for all the scenarios and approaches considered. Results are shown in Figure 3 for the Renewables approach in each scenario, and also for the only other two cases where these changes affect the achievement of the 2025 target. 


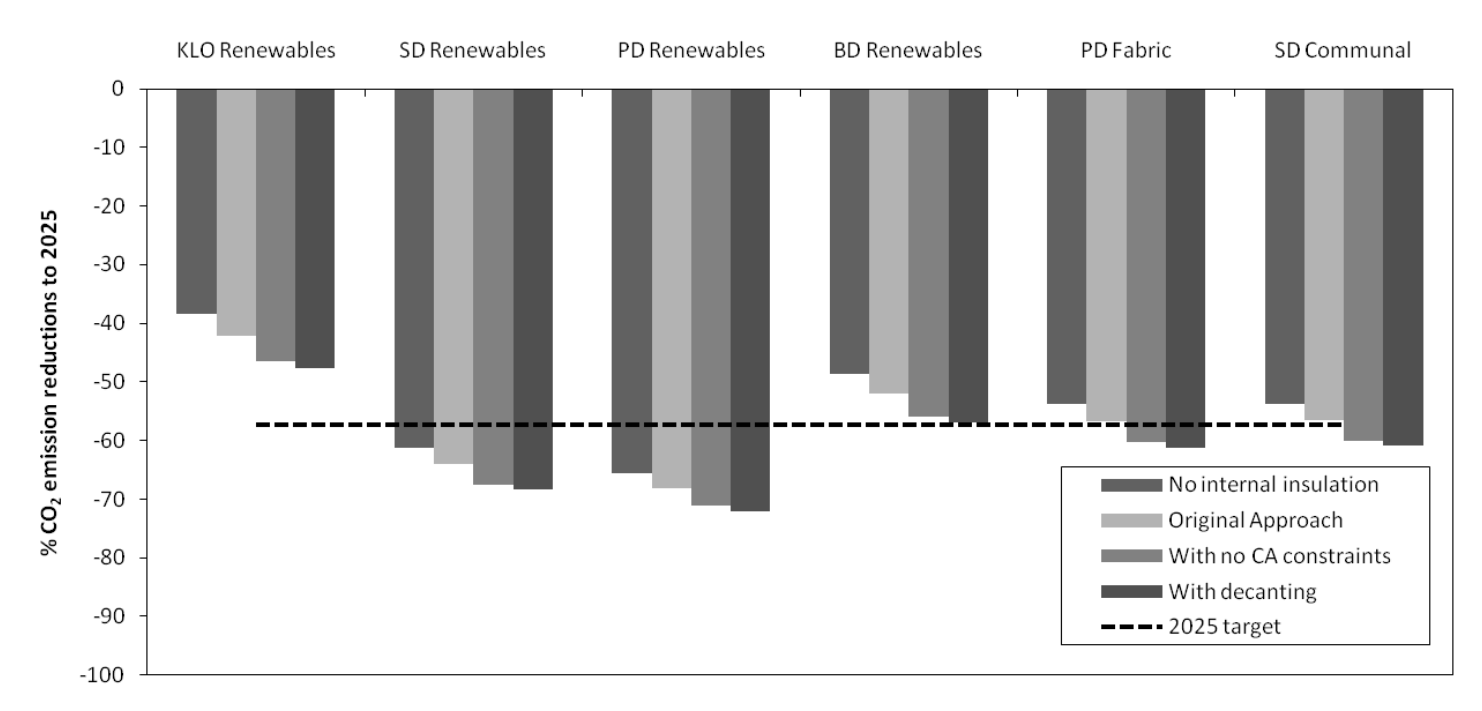

Fig. 3. Impact of changing approach to solid wall insulation on $\mathrm{CO}_{2}$ emissions

If internal insulation is not installed in void properties, this leads to the emission cuts achieved by 2025 being reduced by approximately $3 \%$ in each case. Decanting residents or externally insulating conservation area estates has very similar impacts — cuts of around $5 \%$ for the former and $4 \%$ for the latter — as in both cases the majority of solidwalled homes receive insulation. Emission reductions are slightly greater where decanting is possible, as this change enables floor insulation to be installed, and for all estates to be insulated (homes on listed estates remain untreated where only the conservation area constraint is removed).

By either decanting residents or insulating externally, the Fabric approach in the PD scenario and the Communal approach in the SD scenario are both able to meet the 2025 target. This implies that decanting residents to install internal insulation could be used as an alternative strategy to the installation of energy supply technologies to achieve deeper emission cuts beyond those achieved through the Fabric approach.

\subsubsection{Use of solar PV and solar thermal}

The results presented above for the Renewables approach assume that no solar PV or solar thermal panels can be installed on listed estates or estates in conservation areas, so 
as to maintain the external appearance of these buildings. The implications of assuming that solar panels can be installed on all conservation area estates (but not listed estates) were explored, to identify the potential for increased emission cuts if this constraint was removed.

The results indicate that allowing solar PV and solar thermal installations in conservation areas leads to increased emission reductions of $4 \%$ in each scenario (Figure 4). These further emission reductions increase the confidence that the 2025 target is met for SD and $\mathrm{PD}$, and reveal potential to achieve emission cuts beyond $70 \%$ by 2025 .

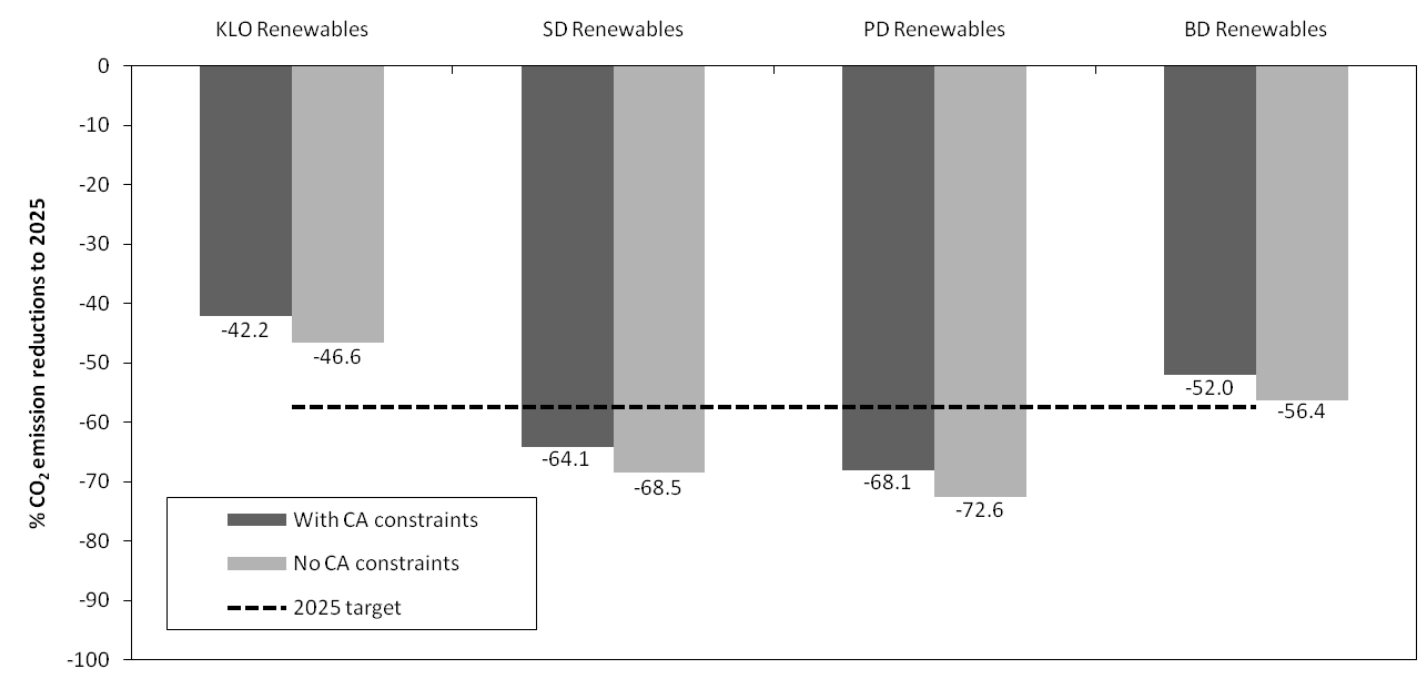

Fig. 4. Impact of removing constraints on use of solar PV and solar thermal

\subsection{Meeting the GLA's 2025 target}

Taking into account the availability of other carbon reduction measures that could be applied on Peabody stock, the original approaches to refurbishment considered above were modified to identify a variety of approaches that meet the GLA target. Considering the issue of likelihood that an approach is successful given the uncertainties in the model, a Good Confidence approach was also devised. This is the least cost approach 
from a whole-life costing perspective (see Reeves 2009) for which the 2025 target is met with a good degree of confidence, as defined previously. A Maximum approach for each scenario combined all measures under consideration that led to emission reductions by 2025 . The resultant approaches for each scenario are given below.

\subsubsection{Keeping the Lights On}

For this scenario, no combination of measures that would allow the GLA's target to be met was possible.

\subsubsection{Sustainable Development}

Six approaches are put forward that have potential to meet the 2025 target (Table 8). The Good Confidence approach relies on decanting residents so that homes can be internally insulated, and installing district heating, communal biomass boilers and solar thermal on all suitable estates.

Table 8. Approaches to meet the 2025 target for the SD scenario

\begin{tabular}{lll}
\hline Approach & Description & $\begin{array}{l}\mathbf{C O}_{2} \text { emission } \\
\text { reductions to } \\
\text { 2025 }\end{array}$ \\
\hline Biomass & Fabric; District Heating; Biomass Boilers & $59 \%$ \\
Decanting & Fabric with decanting; District Heating & $61 \%$ \\
Solar PV & Fabric; District Heating; Solar PV & $63 \%$ \\
Renewables & Fabric; CHP; District Heating; Solar PV; Solar Thermal & $64 \%$ \\
Good & Fabric with decanting; District Heating; Solar Thermal; & $64 \%$ \\
Confidence & Biomass boilers & \\
Maximum & Fabric with decanting; Biomass Boilers; District Heating; & $73 \%$ \\
& Solar PV; Solar Thermal; GSHPs; ASHPs &
\end{tabular}

\subsubsection{Power Down}

The Power Down scenario is the most successful of the scenarios modelled in terms of emission reductions, due to the combination of low energy demand and increased availability of low carbon energy. As a result, a number of distinct approaches could be employed to meet the 2025 target (Table 9). 
Table 9. Approaches to meet the 2025 target for the PD scenario

\begin{tabular}{lll}
\hline Approach & Description & $\begin{array}{l}\mathbf{C O}_{2} \text { emission } \\
\text { reductions to } \\
\mathbf{2 0 2 5}\end{array}$ \\
\hline Solar Thermal & Fabric; Solar Thermal & $58 \%$ \\
Heat pumps & Fabric; GSHPs & $59 \%$ \\
District Heating & Fabric; District Heating; & $60 \%$ \\
Communal & Fabric; CHP; District Heating & $61 \%$ \\
Biomass & Fabric; Biomass Boilers & $61 \%$ \\
Decanting & Fabric with decanting & $61 \%$ \\
Solar PV & Fabric; Solar PV & $64 \%$ \\
Good & Fabric with decanting; District Heating; Biomass boilers & $67 \%$ \\
Confidence & & \\
Renewables & Fabric; CHP; District Heating; Solar PV; Solar Thermal & $68 \%$ \\
Maximum & Fabric with decanting; Biomass Boilers; District Heating; & $76 \%$ \\
& Solar PV; Solar Thermal; GSHPs; ASHPs &
\end{tabular}

\subsubsection{Breaking Down}

For this scenario, the GLA target could only be achieved through a "Maximum" approach, comprising the Fabric approach (with decanting), district heating, communal biomass boilers, solar PV and solar thermal, which achieves a cut in emissions of $60 \%$ by 2025 . Given the uncertainties in the model, it is some way short of meeting the target with a good level of confidence.

\subsection{Impacts of stock type}

Peabody stock differs markedly in its makeup from other social housing stock and other housing in London (Table 10). The emission reductions achieved in distinct types of Peabody housing were assessed in order to identify the implications of this research for other social landlords in the UK with differing stock profiles. 
Table 10. Characteristics of Peabody stock relative to other social housing and housing in London

\begin{tabular}{|c|c|c|c|c|}
\hline $\begin{array}{l}\text { Housing } \\
\text { type/location }\end{array}$ & $\begin{array}{l}\% \text { homes } \\
\text { built prior } \\
\text { to } 1945\end{array}$ & $\begin{array}{l}\% \text { homes } \\
\text { flats }\end{array}$ & Breakdown of non-flats & Source \\
\hline Peabody & $51 \%$ & $82 \%$ & $\begin{array}{l}\text { Remaining } 18 \% \text { mostly terraced or } \\
\text { semi-detached }\end{array}$ & Peabody \\
\hline $\begin{array}{l}\text { All housing } \\
\text { associations }\end{array}$ & $19 \%$ & $42 \%$ & $\begin{array}{l}48 \% \text { terraced or semi-detached, } \\
10 \% \text { detached }\end{array}$ & $\begin{array}{l}\text { CLG } \\
(2008)\end{array}$ \\
\hline London & $58 \%$ & $45 \%$ & $\begin{array}{l}33 \% \text { terraced, } 22 \% \text { semis or } \\
\text { detached }\end{array}$ & $\begin{array}{l}\text { CLG } \\
(2006)\end{array}$ \\
\hline $\begin{array}{l}\text { London social } \\
\text { housing }\end{array}$ & $31 \%$ & $74 \%$ & $\begin{array}{l}20 \% \text { terraced, } 6 \% \text { semis or } \\
\text { detached }\end{array}$ & $\begin{array}{l}\text { CLG } \\
(2006)\end{array}$ \\
\hline
\end{tabular}

Peabody stock was broken up into five categories. Electric estates are those having mostly (or entirely) electric heating. All but one of these estates were built in the last 20 years. Scattered estates consist of street properties with a greatly varying age profile. The remaining estates were divided up according to their date of construction: Modern estates are those built after 1991; Recent estates are those built between 1951 and 1991; Old estates are those built before 1951, and are typically solid-walled blocks of flats. The emission reductions achieved for different stock types are illustrated for the Good Confidence approach to meeting the 2025 target in the PD scenario (Table 11). Prior to refurbishment, emissions vary significantly between Peabody dwelling types, and are all below the UK average, as is typical for social housing. After refurbishment, emissions per resident are broadly similar across all stock types, between 0.6 and 0.7 tonnes per annum. The greatest percentage reductions are achieved on older estates and estates with electric heating — those which currently have higher emissions and the greatest potential for emission cuts. 
Table 11. Emissions and emission cuts by stock type: PD scenario, Good Confidence approach

\begin{tabular}{lllll}
\hline $\begin{array}{l}\text { Stock Type } \\
\text { (and \% of } \\
\text { stock) }\end{array}$ & $\begin{array}{l}\text { 2006 emissions per } \\
\text { home per annum } \\
\text { (tonnes) }\end{array}$ & $\begin{array}{l}\text { 2006 annual } \\
\text { emissions } \\
\text { per resident } \\
\text { (tonnes) }\end{array}$ & $\begin{array}{l}\text { Emission } \\
\text { reductions to 2025 } \\
\text { (PD scenario) }\end{array}$ & $\begin{array}{l}\text { 2025 annual } \\
\text { emissions } \\
\text { per resident } \\
\text { (tonnes) }\end{array}$ \\
\hline Modern (14\%) & 2.4 & 1.3 & $47 \%$ & 0.7 \\
Recent (14\%) & 2.6 & 1.3 & $54 \%$ & 0.6 \\
Old (51\%) & 3.4 & 2.0 & $70 \%$ & 0.6 \\
Electric (3\%) & 4.0 & 2.4 & $73 \%$ & 0.7 \\
$\begin{array}{l}\text { Scattered } \\
(18 \%)\end{array}$ & 4.4 & 1.8 & $62 \%$ & 0.7 \\
$\begin{array}{l}\text { Peabody } \\
\text { Average }\end{array}$ & 3.4 & 1.5 & $67 \%$ & 0.6 \\
UK Average & 6.1 & & & N/A
\end{tabular}

\subsection{Beyond the 2025 target}

The $60 \%$ emission reduction goal set by the GLA is a milestone on an intended trajectory to emission cuts of the order of $80-90 \%$, with further rapid reductions intended from 2025 to 2030 (GLA, 2007). This implies a need to assess the viability of achieving cuts that go beyond the GLA target.

The greatest cut in emissions achieved to 2030 for the initial modelled approaches was $72 \%$ for the Renewables approach in the PD scenario. The Maximum approach for the PD scenario achieves an $82 \%$ reduction by 2030 , assuming that all gas central heating systems are removed and replaced with electric heating.

These results highlight that to go beyond the 2025 target, towards reductions in the range $80-90 \%$, substantial further stock improvements may be required, which would need to include extensive use of more costly technologies such as solar PV and more disruptive approaches to refurbishment, such as installing internal insulation. Emission targets on this scale would also put greater pressure for change on constraints external to Peabody, such as planning policies in conservation areas, levels of domestic energy demand and the emissions associated with grid electricity. 


\subsection{Achieving Zero-Carbon}

For the purposes of this study, an existing estate has been described as "zero-carbon" if its net on-site carbon emissions are zero or less. Net emissions are the total carbon emissions arising from on-site energy use less any emissions saved due to on-site electricity generation. As a result, an estate where fossil fuels are used (for example, gas as a fuel for condensing boilers) can still achieve zero net carbon emissions if sufficient on-site generation takes place to "offset" those emissions.

To carry out the assessment of whether zero net carbon emissions can be achieved across Peabody stock, the scenario which led to the greatest levels of emission cuts, Power Down, was taken as a starting point. Three approaches to refurbishment that go beyond this starting point were considered, based upon changing three key assumptions: the technologies installed; energy demand from residents; the availability of biomass CHP (as an alternative to gas-fired CHP). The impacts of biomass CHP were explored as it is the only technology apart from solar PV and gas-fired CHP that can be used on Peabody estates to offset emissions through the generation of electricity. Its impacts were not explored through the original refurbishment approaches as it is not considered to be a mature technology for applications on the scale of Peabody estates (RAB 2007), but this situation could potentially change by 2030 .

The resulting four refurbishment approaches considered are shown in Table 12, and the emission reductions achieved by 2030 are shown in Table 13 . 
Table 12. Approaches to achieve zero net carbon emissions

\begin{tabular}{ll}
\hline Method & Description \\
\hline Base & As for the Renewables approach of the PD scenario. \\
Maximum & $\begin{array}{l}\text { As for the Maximum approach described previously. Furthermore, it } \\
\text { is also assumed that gas boilers are replaced with electric storage } \\
\text { heaters (as with the carbon intensity of grid electricity being assumed } \\
\text { to be less than } 0.185 \mathrm{kgCO}_{2} \mathrm{e} / \mathrm{kWh} \text { in } 2030, \text { this is the lowest carbon } \\
\text { option). It is also assumed that gas cookers are replaced with electric } \\
\text { cookers in each home where gas heating is removed for the same } \\
\text { reason. }\end{array}$ \\
& $\begin{array}{l}\text { As for the Maximum approach, but with resident demand for energy } \\
\text { reduced by up to } 40 \% .\end{array}$ \\
Low Demand & As for the Low Demand approach, but with biomass CHP installed \\
instead of biomass boilers
\end{tabular}

Table 13. Average annual emissions in 2030

\begin{tabular}{lll}
\hline Method & $\mathbf{2 0 3 0}$ average emissions $/ \mathbf{t C O}_{\mathbf{2}} \mathbf{e}$ & \% emission reduction \\
\hline Base & 0.9 & $72 \%$ \\
Maximum & 0.5 & $84 \%$ \\
Low Demand & 0.4 & $88 \%$ \\
Low Demand and & 0.3 & $91 \%$ \\
Biomass CHP & &
\end{tabular}

The results indicate that even if maximum use is made of technical interventions and with significant energy demand reductions from residents, zero-carbon status is not achieved for Peabody stock. The principal barrier is the relatively small amount of roof space suitable for solar PV on Peabody estates. This is a particular issue on the older estates, which are multi-storey and often have heavily-shaded roofs, giving a low area of suitable roof space per dwelling.

A remaining approach to move towards zero carbon emissions would be to assume a reduced carbon intensity of grid electricity, beyond the already low figure assumed for 2030 of $0.171 \mathrm{~kg} \mathrm{CO}_{2}$ per $\mathrm{kWh}$ (around a third of present-day levels). However, reducing this figure towards zero does not lead to zero net carbon emissions being achieved. This is because as the emissions associated with electricity use are reduced, 
the carbon emission reductions that result from displacing grid electricity through onsite generation become smaller (indeed, they are assumed to fall more rapidly, as illustrated in Figure 1). This situation leads to the conclusion that zero-carbon grid electricity appears to be necessary to achieve zero carbon emissions for Peabody stock, coupled with a modified approach to energy supply.

If grid electricity is produced entirely from zero-carbon sources, then if any fossil fuels (such as natural gas) are used either directly or indirectly to provide energy for Peabody estates, zero-carbon status can not be achieved. In this context and using existing technologies, only electricity or biofuels could be used to provide energy for Peabody estates if zero-carbon status is to be achieved. Gas-fired individual heating systems could be replaced by electric heating, either in the form of storage heaters or, where feasible, heat pumps. Communal systems could only be used as part of a zero-carbon strategy if they could be fuelled entirely by biofuels, such as wood pellet or biogas.

\section{Discussion and Conclusions}

\subsection{GLA target}

A key finding of the present work is that, in the absence of changes in external factors, even if Peabody were to use every technology considered to the greatest possible extent on its stock there is no guarantee that the GLA target would be met. Significant changes in external factors are also necessary, with two critical ones being a constraint on resident demand for energy and an increase in the availability of low carbon energy (grid electricity or district heating). With a suitable combination of stock improvement measures and broader contextual change, the results indicate that the GLA's 2025 target can be met for Peabody stock. These conclusions echo the GLA's own analysis of the viability of meetings its 2025 carbon reduction target (GLA, 2007) and findings from 
similar studies on carbon reduction from existing housing (Boardman, 2007; EST, 2008).

These findings hold for each type of Peabody stock considered, implying that they are likely to apply equally to other social landlords, many of which manage more modern stock for which emission cuts are more challenging to achieve through technical measures.

If beneficial external conditions are in place, as they are for the SD and PD scenarios, the GLA target can be met, and the extent of refurbishment required depends on the extent of emission reductions already achieved by external factors. For the two successful scenarios considered in this research, this could be achieved by insulating all solid-walled estates (with residents being decanted on estates in conservation areas to achieve this), connecting up to $25 \%$ of estates to district heating networks and installing either communal biomass boilers or solar micro-generation technologies.

This represents a radical change in the current approach to refurbishment for Peabody, as it would for other social landlords with similar stock. However the need for this scale of refurbishment is consistent with findings from previous research on achieving deep emission cuts in UK housing. The affordability of this work is a key issue, and research conducted in parallel to the present study has identified that this action would not be financially viable for Peabody, and is likely not to be affordable for other social landlords in their current operating context (Reeves et al., 2009).

\subsection{Zero carbon}

The zero-carbon target could only be achieved if zero-carbon grid electricity is available and if no fossil fuels are used to provide energy for Peabody estates. This finding has a number of implications. 
Firstly, it highlights that the zero-carbon status of a building depends on its context, not just the building itself. As a result, zero-carbon status cannot always be achieved through technical measures alone, even if they are applied to the maximum possible extent. A further implication is that a zero-carbon building that achieves this status through displacing sufficient grid electricity to offset any fossil fuels used onsite could lose its zero-carbon status in future years if the carbon intensity of the grid declines. A second implication is that if zero-carbon is the long-term goal for an estate, rather than, for example, emission cuts of $60 \%$, this may alter decisions on which technologies are most appropriate to install. For example, gas-fired CHP may be effective at reducing emissions over the lifetime of the installed boilers, but installing communal infrastructure may not be a beneficial investment with a view to achieving zero carbon emissions, unless a zero-carbon energy source can be feasibly used to fuel communal heating on that site. This could be a particular issue in London, and other urban areas, where the use of biomass heating could be constrained due to concerns about particulate pollution (BERR, 2008).

Finally, it should be stressed that achieving a zero-carbon grid by 2030 is likely to be both technically and politically challenging. The technical viability of developing a zero-carbon grid is uncertain, although the Centre for Alternative Technology has outlined a broad approach for achieving this in the UK by 2027 (CAT, 2007), and a close to zero-carbon grid by 2030 has been recently called for by the UK's Committee on Climate Change (CCC, 2008). The political viability of this goal is much more doubtful, as achieving this would require radical changes in the perceived level of action required to mitigate climate change on the part of both the public and Government. 


\subsection{Implications for social landlords}

The results for Peabody stock indicate the need for a substantial deployment of carbon reduction measures to achieve deep cuts in carbon emissions for all stock types considered, even in a context of demand reduction and significant grid decarbonisation. This finding implies that action of a similar order is likely to be required for other social landlords, though the particular measures that will be appropriate will differ according to each particular landlord's stock profile.

The scale of the work required implies that carrying out these measures could entail a significant shift in the responsibilities of social landlords towards their stock. The present obligation to maintain the good condition of their stock would be extended to incorporate a responsibility to actively intervene to comprehensively reduce stock emissions.

The relative difficulty identified of achieving emission reductions in Peabody's more modern stock, which is more typical of the broader housing association sector, implies that greater reductions need to be achieved in older, less efficient homes to offset this. This could imply that landlords with older stock such as Peabody should look to achieve reductions beyond any given percentage target applied to the housing sector (e.g. beyond $80 \%$ by 2050$)$.

\subsection{Recommendations for policymakers}

The two key recommendations for Government arising from this research are the need to drive decarbonisation of the grid and to constrain or reduce domestic energy demand. With regard to grid decarbonisation, the targets put forward by the Committee on Climate Change (2008) for substantial grid decarbonisation offer a useful goal to work towards, that would reduce the need for emission cuts to be achieved through technical measures applied to housing. Whilst residents' demand for energy is dependent to a 
large degree on broad social causes, a wide range of policies are available to Government to help reduce domestic energy demand, and these should be actively pursued. Specific policy recommendations are beyond the scope of this paper, but due to the apparent need for cost savings as a motivation for behaviour change amongst social housing residents (Reeves, forthcoming), policies that put a price on carbon emissions appear to be of some importance.

\section{$5.5 \quad$ Future research}

The research reported here has identified the need for the use of extensive technical measures to achieve deep emission cuts in existing social housing homes. Parallel research has identified that a lack of financial viability and acceptability amongst residents are key barriers to carrying out the identified interventions (Reeves, forthcoming). Future research could productively build upon these findings and address some of the limitations of this research by studying actual low-carbon refurbishments of existing social housing estates over coming years. Such research could provide valuable learning on the emission cuts achieved in practice, on the costs of refurbishment, on the effectiveness of innovative funding mechanisms and on the experiences and views of key stakeholders (particularly residents and social housing staff).

\section{Acknowledgements}

This research has been carried out through an EPSRC-funded industrial CASE studentship, delivered through the Integration of New and Renewable Energy in Buildings (INREB) Faraday partnership, with support from Peabody. The authors wish to thank Rob Wall and Bev Allan at De Montfort University, Peter Rickaby of Rickaby Thomson Associates, and Simon Graham, Mary Popham and Nic Wedlake at Peabody 
for feedback on this research. Thanks also to Steven Firth at Loughborough University for the use of data from the Community Domestic Energy Model.

\section{References}

BERR (2008). Renewable Energy Strategy Consultation. London, Department for Business, Enterprise and Regulatory Reform.

Boardman, B. (2007). Home Truths. Oxford, Environmental Change Institute.

Boardman, B., Darby, S., Killip, G., Hinnells, M., Jardine, C., Palmer, J., Sinden, G. (2005). 40\% House Report. Oxford, Environmental Change Institute.

BRE (2001). BREDEM-8 Model Description. Garston, Watford, BRE.

BRE (2005). Reducing Carbon Emissions from the UK Housing Stock. Garston, Watford, BRE.

BRE (2006). SAP 2005: The Government's Standard Assessment Procedure for Energy Rating of

Dwellings. Garston, Watford, BRE.

CAT (2007). Zero Carbon Britain. Machynlleth, Wales, Centre for Alternative Technology.

CCC (2008). Building a low-carbon economy - the UK's contribution to tackling climate change. London, Committee on Climate Change.

CCC (2009). Meeting Carbon Budgets - the need for a step change. London, Committee on Climate Change.

CLG. (2006). English House Condition Survey - 2003 Regional Report. Department for Communities and Local Government Retrieved 27/10/09, from

http://www.communities.gov.uk/archived/publications/housing/englishhousecondition6.

CLG. (2008). English House Condition Survey - Stock Profile. Department for Communities and Local Government Retrieved 27/10/09, from http://www.communities.gov.uk/housing/housingresearch/housingsurveys/englishhousecondition /ehcsdatasupporting/ehcsstandardtables/stockprofile.

Cooper, J. and K. Jones. (2008). Sustainable social housing maintenance. Retrieved 27/10/09, from http://www.idcop.soton.ac.uk/outcomes/IDCOP\%20WP\%202.1\%20Questionnaire-Analysis.pdf. 
DECC (2009). The UK Low Carbon Transition Plan. London, Department of Energy and Climate Change.

Defra (2007). Guidelines to Defra's GHG conversion factors for company reporting. London, Department for the Environment and Rural Affairs.

EST (2008). Towards a long-term strategy for reducing carbon dioxide emissions from our housing stock. London, Energy Saving Trust.

GLA (2007). Action today to protect tomorrow: the Mayor's climate change action plan. London, Greater London Authority.

Johnston, D., Lowe, R., Bell, M. (2005). An exploration of the technical feasibility of achieving $\mathrm{CO}_{2}$ emission reductions in excess of $60 \%$ within the UK housing stock by the year 2050. Energy Policy 33(13): 1643.

Killip, G. (2008). Building a Greener Britain. London, Federation of Master Builders.

Natarajan, S. and G. J. Levermore (2007). Domestic futures--Which way to a low-carbon housing stock? Energy Policy 35(11): 5728-5736.

PIRC. (2008). Climate Safety. Public Interest Research Centre. Retrieved 27/10/09, from http://climatesafety.org/wp-content/uploads/climatesafety.pdf.

RAB (2007). The Role of Onsite Energy Generation in Delivering Zero Carbon Homes. London, Renewables Advisory Board.

Reeves, A. (2009). Achieving deep carbon emission reductions in existing social housing: the case of Peabody. PhD thesis, Institute of Energy and Sustainable Development, De Montfort University, Leicester.

Reeves, A. (forthcoming). Making it viable: exploring the influence of organisational context on efforts to achieve deep carbon emission cuts in existing UK social housing. Submitted January 2010 to "Energy Efficiency".

Reeves, A., Taylor, S.C., Fleming, P.D. (2009). Deep carbon emission reductions in existing UK social housing: are they achievable, and how can they be funded? ECEEE Summer Study: Act! Innovate! Deliver! Reducing energy demand sustainably, La Colle sur Loup, France, European Council for an Energy Efficient Economy.

Schwartz, P. (1991). The Art of the Long View. New York, John Wiley \& Sons. 
Tyndall Centre. (2005). Decarbonising the UK: Energy for a climate conscious future. Retrieved 27/10/09, from http://www.tyndall.ac.uk/content/decarbonising-uk-energy-climate-consciousfuture.

UKGBC (2008). Low Carbon Existing Homes. London, UK Green Building Council.

UKGBC (2009). Pay as you save: financing low energy refurbishment in housing. London, UK Green Building Council.

WWF (2008). How Low? London, WWF. Retrieved 27/10/09 from http://assets.wwf.org.uk/downloads/how_low_report.pdf. 